\title{
Evaluation and Analysis of Administra- tive Monopoly in China's Oil Industry
}

\author{
GAO YAN AND QIAN PU
}

\begin{abstract}
China's oil and petrochemical industry is under administrative monopoly. Administrative monopoly, according to the Unirule Institute of Economics, refers to trade monopoly from concessions granted and the monopolistic power conferred by administrative departments through administrative documents on business entities - enterprises or administrative institutions that are also engaged in profit-making activities. Administrative monopolies come in various forms, including barriers to entry, special privileges and price regulation, which lead to multi-level monopolistic powers and status. The administrative monopoly in China's oil and petrochemical industry has evolved from the previous planned economy. Although the central government has the motivation to reform stateowned enterprises to increase revenue, which has been mainly from taxation, it lacks the impetus to break the administrative monopoly. This article shows that the barriers to entry form high monopoly prices and transfer the consumer surplus into business profit, which is unfair and distorts income allocation. After analysing the forms and origins of administrative monopoly in China's oil and petrochemical industry, the article demonstrates that administrative monopoly causes distorted factor prices, compromises fair trade, reduces efficiency and causes loss of social welfare and degradation of business ethics. This article also proposes judicial, administrative and market-oriented reform solutions.
\end{abstract}

Keywords: oil industry, administrative monopoly, institutional innovation

\section{Introduction}

Administrative monopoly occurs mainly in the establishment of barriers to entry and price regulation. The latter can be divided into two forms, regulation of seller's or selling priceand regulation of the buyer's or buying price, which is reflected by the preference and even payment exemption to those with administrative monopoly for resources and other inputs. As long as there are institutional barriers to entry, even with other conditions the same as those in free competition, administrative monopoly will lead to high prices, low output and welfare loss under certain conditions of demand. The employment of barriers 
to entry established by administrative departments to form high monopoly prices and transfer the consumer surplus into business profits represents an unfair and distorted income allocation mechanism. If the resources equivalent to the monopoly profits were diverted to other purposes decided by the market, more products would be produced. The value of these products would be the opportunity loss of the monopoly profit (distorted income allocation) resulting from the administrative monopoly, i.e. loss of social welfare.

In fact, in the administrative monopoly, the oligarchies in China's oil industry are surrogates of an interest group - the Communist Party of China (CPC) - in different stages and phases. In the power game, once the political influence of one political league subsides, the new political power holders take office and stage political liquidation of the traditional interest groups, tightening anti-corruption efforts to gain the support of the public and to establish their legitimacy. The current anti-corruption movements in China seem to cater to the public's call for the investigation and prosecution of the heads of the oil industry monopolies, thereby gaining public support for the new political leaders. This act establishes a positive image for the new administration. Therefore, it is fair to say that the current oil reform is more of a political act than an economic one. Superficially, the central government is seeking reforms for central government-led state-owned enterprises (SOEs), but in essence, the central government is seeking to enhance the market status of the central-government-led SOEs by upholding administrative monopolies and consolidating the rule of the CPC. It has always been a key goal to consolidate the central-government-led SOEs as a foundation of the CPC's eternal rule over China, the bottom line of China's reforms. This has been understood by all the interest groups and can be found in various speeches given by the new political leaders. However, it begs the question whether theories and practices support such a proposition. Our research and analysis is based on the proposition that reforms should be undertaken using market rules and mechanisms. Understanding this is very important for evaluating China's oil industry.

This article analyses and explains the forms, origins and consequences of administrative monopoly in China's oil and petrochemical industry. We demonstrate that administrative monopoly causes distorted resource prices and compromises fair tradeand we propose a solution to break administrative monopoly by judicial, administrative and market means. 


\section{Formation and Evolution of Administrative Monopoly in the Oil Industry}

Before 1979, China's oil industry was totally within the planned economy. Crude and processed oil were incorporated into a national plan for centralized distribution and hierarchical management. A unified purchase and sales channel was established in the countryand oil enterprises only needed to fulfil the targets set for them.

After 1978, declining output and losses by oil enterprises highlighted the low efficiency of China's oil industry. As a result, the oil industry was reformed several times. A brief history goes as follows (see Figure 1). In 1979, the State Council approved the output contract policy for the former Ministry of Petroleum Industry, stipulating that the oil that exceeded the output target could be sold at the international price and the balance could be used for oil exploration and exploitation, hence the coexistence of planned and market-oriented oil distribution systems. To facilitate international cooperation on offshore oil exploitation, the China National Offshore Oil Corporation (CNOOC) was established in March of 1982. CNOOC was to be responsible for international cooperation in this regard. In 1983, oil-refining enterprises in all sectors were integrated to form the China Petrochemical Corporation (Sinopec). In September 1988, the Ministry of Petroleum Industry was dissolved and reorganized into the China Petroleum and Natural Gas Corporation (CNPC) to manage onshore oil companies. Consequently, in China's oil industry, exploration and exploitation is dominated by CNPC, refining is monopolized by Sinopec and offshore oil exploration and exploitation is controlled by CNOOC. In 1998, China's oil industry was reorganized to divide the oil business into three geographic parts, south, north and offshore, respectively controlled by Sinopec, CNPC and CNOOC, which are all vertically integrated. The monopoly in China's oil industry was thus transferred from the industry chain to regions.

After the Ministry of Petroleum Industry was dissolved in 1988, CNPC, Sinopec and CNOOC gained some industry management power in their respective areas. The existing monopoly in China's oil industry stems from the reform of the oil distribution system that began in 1994 and was further consolidated by subsequent clean-up and rectification policies. In May 1999, the General Office of the State Council issued an administrative regulation to institute the monopoly of the three companies: Opinions on Cleaning-up and Rectifying Small Refineries and 
Regulating the Distribution Order of Crude Oil and Processed Oil (Guo Ban Fa, 1999, No. 38, hereafter referred to as Document No. 38).

This document intensifies the control of crude oil by CNPC and Sinopecand empowers the two companies to monopolize oil refining and wholesaling of processed oil. To enter the upstream sectors, private and other companies need to cooperate with the CNPC to exploit low-yield areas determined by the CNPC and bear all the investment risks. Moreover, they must turn 20 per cent of the exploited oil over to the CNPC at no cost and sell the remaining 80 per cent to the CNPC at a price set by the CNPC. ${ }^{1}$ In the oil refining sector, Sinopec and CNPC are given the right to integrate local refineries. The wholesaling of processed oil (gasoline, kerosene and diesel oil, the same below) produced by refineries in China is exclusively carried out by the wholesale enterprises of CNPC and Sinopec. This document makes it difficult for independent wholesalers of processed oil to survive, let alone flourish.

The unveiling of Document No. 38 closely followed the approval of the reform of institutions under the State Council by the 1st Session of the 9th National People's Congress in March 1998. The plan set up two super-large groups: CNPC and Sinopec. The two groups were granted monopoly in the industry before they were officially established so that they could expand rapidly to cope with the fierce competition of multinational oil companies after China's accession to the World Trade Organization (WTO). China's oil and petrochemical industry had long been protected and supported by government quota and permit systems, high tariff barriers and market entry regulations to restrict the import of crude and processed oiland to exclude foreign companies from engaging in the wholesale and retail of crude and processed oil. Domestic oil companies that have grown up under the protection of such policies can hardly compete with multinational companies. Therefore, some think that 'to give the two groups monopoly before liberalizing the industry can rapidly increase their competence and set up a wall to ward off foreign capital. ${ }^{2}$ Moreover, in the name of safeguarding the order of the market economy, clean-up and rectification policies were issued to further consolidate this mechanism.

The formation of the existing monopoly mechanism in the processed oil and crude oil markets was facilitated by policies promulgated by ministries and commissions of the State Council to advance the market economy, cope with international competition after China's accession to the WTO and undertake reform. The present monopoly in China's oil industry is not a result of market competition, but of top-down changes enacted by 


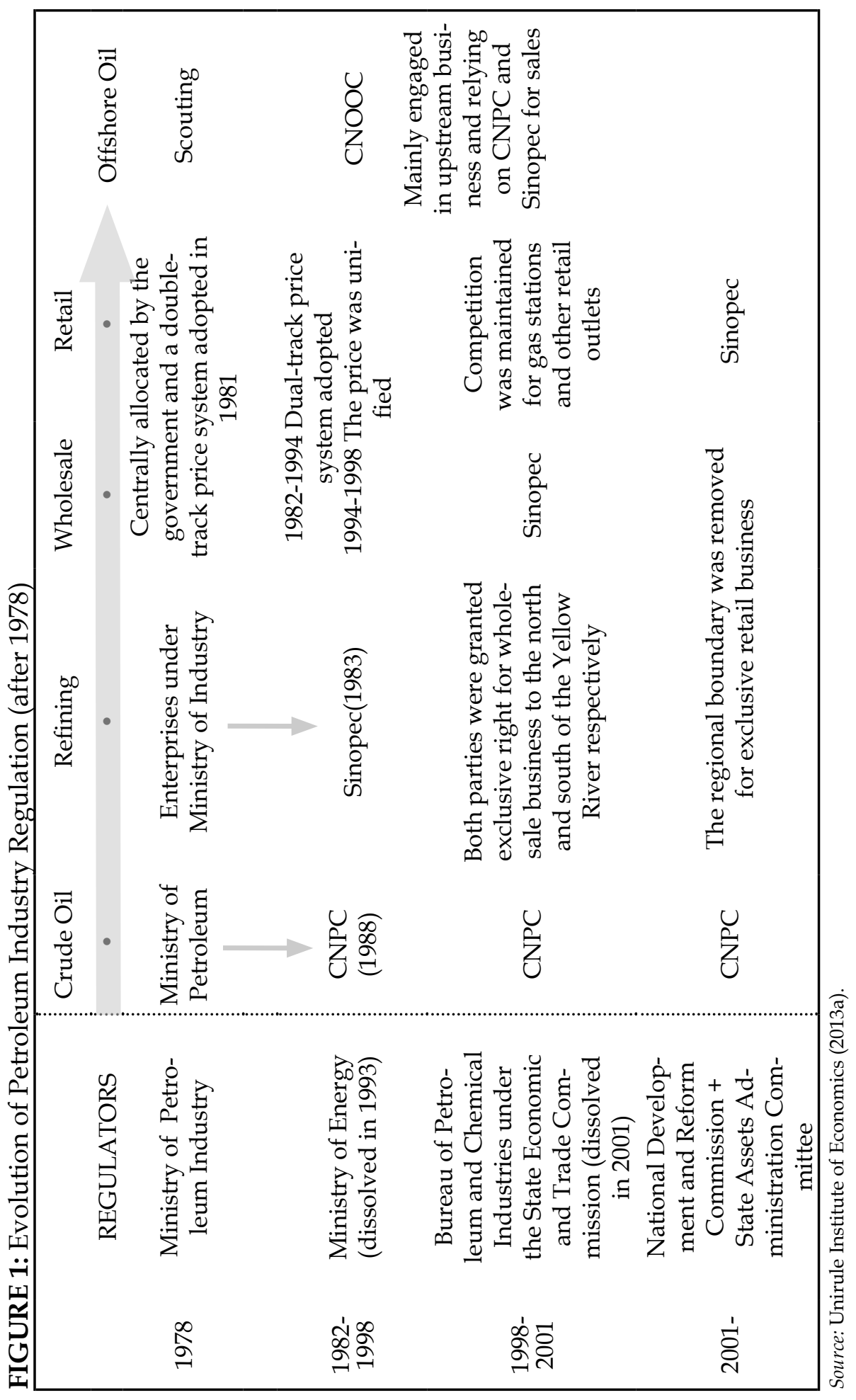


administrative departments by administrative means. Therefore, it has had a strong administrative character from the very beginning.

\section{Analysis of the Internal Mechanism for Administrative Monopoly in the Oil Industry}

In addition to the fact that administrative monopoly in China's oil industry was born out of the previous planned economy system, the major reason why administrative departments create, ensure, expand and advance a monopoly in the oil industry by regulatory means is that closely bonded interest groups are formed between them and monopoly enterprises. According to the theory of economic regulation created by Peltzman and other economists, the utility function of a regulator is not to maximize social welfare but its own political interest. ${ }^{3}$ However, in China, because the administrative departments are completely different from their US counterparts in formation and operating mechanisms, they have different objectives. Yu Hui (2000) thinks that in a regulated market, legislators and regulators do not need to pursue maximum votes. Instead, they follow the same objectives as enterprises, i.e. the maximization of utility and taxation.

Resource industries, especially the oil industry, feature relatively high entry costs and low price elasticity of demand, which is conducive to helping oil companies get monopoly profits by setting high monopoly prices. The central government and administrative departments of different industries have different interest claims. The central government can share the revenue through taxation, while government departments (and even officials) can 'set rent' and 'seek rent' through institutional barriers to entry and preferential policies to share the monopoly interest.

\section{Low Price Elasticity of Demand Gives Rise to High Monopoly Profits}

The industry-specific distribution of administrative monopoly in China is actually the result of a common choice by administrative departments and specific enterprises. When setting institutional barriers to entry and unveiling preferential policies for certain enterprises, administrative departments will consider the costs and benefits to a certain degree. When the demand is less elastic, the price rise will increase the benefits of monopolists. Multiple studies indicate that the oil industry lacks the price elasticity of demand, which makes it possible for oil companies to set and maintain high monopoly prices to gain high monopoly returns. 
In 2010-2011, the net profits of CNPC, Sinopec and CNOOC totalled RMB 2.06 trillion. During the same period, the profits of industrial enterprises above a designated size in China amounted to RMB 27.18 trillion.

\section{Maximization of the Central Government's Fiscal Revenue}

In this article, central fiscal revenue is used to replace the gains of the central government from administrative monopoly. When the oil industry suffers losses, potential entrants will be blocked, which will hinder the growth of the industry itself. When demand rises rapidly at the established price level, the financial deficit will be highlighted. In this context, it is a practical and natural choice for the government to loosen regulation in exchange for fiscal revenue. After 1978, the low efficiency of China's oil industry was highlighted by declining output and losses of oil enterprises. Therefore, the government loosened regulation of this industry mainly in two aspects. First, it adopted a double-track price system. Secondly, it loosened entry control. From the late 1980s to 2000, many private companies entered the oil and natural gas business.

However, since 2000, the price of mineral resources has been rising around the world. As the resource rent increases, the game in which the government departments at all levels, mineral authorities, central enterprises, local SOEs and private investors take part is becoming increasingly fierce. In reality, the central government is not neutral, but an organization with multiple objectives. Its objectives include social welfare, GDP growth and maximization of fiscal revenue. Essentially, it is a revenue-oriented government. In terms of its approach to economic development, a revenue-oriented government often becomes the principal part of economic activities by controlling or monopolizing social resources. Central enterprises can be deemed carriers for the economic activities of the central government.

In the tax structure of oil enterprises, rents directly attached to oil resources mainly include a resource tax, a mineral resource compensation and a special oil gain levy. The resource tax is a local tax, the mineral resource compensation is divided by the central government and local governments at a ratio of 5:5 or 4:6and the special oil gain levy goes to the central government as non-tax revenue. Among other taxes, those that directly go to the state treasury include consumption tax, business income tax and value-added tax. The rates of these taxes are fairly high. Taxes that go to local governments include urban construction and maintenance tax, education surcharge and a business tax with relatively lower rates. Generally, taxes paid by central enterprises go directly to 
the state treasuryand very little is left for the local government. Sinopec, for example, paid a total of RMB 1.23 trillion taxes in 2001-2011. Of that, RMB 1.14 went to the state taxation and non-tax income of the central government, accounting for 91.98 per cent of the total.

Since the reform of the financial system began, central government revenue now comes mostly from taxation. Although the central government has the motivation to reform SOEs, it lacks the impetus to break the administrative monopoly. Under the current fiscal and taxation system, supporting the expansion of enterprises has become the second best choice of the central government.

\section{Department Rent Interest and In-house Lobbying}

Government departments are the suppliers of administrative monopoly. They are willing to provide administrative monopoly because the government is never completely a representative of public interest. In China's regulation practice, the behaviour of administrative departments and regulated enterprises presents accordance of interestand this is because both parties integrate the functions of government and enterprise (Yu 2008). Even if the parties are separate in form, SOE managers and government officials are within the same promotion hierarchy (see Table 1 ). Because these SOE managers and government officials can exchange their roles easily thanks to a 'revolving door' mechanism, they can be deemed to be in the same group. Therefore, the interest group of the regulated industry still has a strong lobbying force and influence in administrative departments. For instance, after China began to adopt the new resource tax scheme in 2011, CNPC and Sinopec successfully persuaded the central government to raise the threshold of the special oil gain from US\$ 40 to US\$ 55, basically offsetting the rising costs caused by the resource tax.

TABLE 1: Executives from Administrative Departments in Three Oil Giants (in \%)

\begin{tabular}{|l|l|l|l|}
\hline & 2006 & 2007 & 2010 \\
\hline CNPC & 58.33 & 54.55 & 42.86 \\
\hline Sinopec & 63.64 & 63.64 & 40.00 \\
\hline CNOOC & 40.66 & 44.16 & - \\
\hline
\end{tabular}

Note: Administrative departments include the Petroleum Administration, Ministry of Petroleum Industry, Bureau of Petroleum and Chemical Industries, National Development and Reform Commission, Ministry of Commerce, local development planning committees and trade committees. Those who previously worked at posts above provincial/ministerial level at local governments are also deemed to have worked at administrative departments.

Source: Data compiled from annual reports of CNPC, Sinopec and CNOOC. 
Cross appointments make SOE managers and government officials quite close to each other; the resulting acquaintance between them makes it easier for them to conspire. In addition, as government officials are likely to work in SOEs in the future, they are quite willing to provide preferential policies for SOEs. This can compromise the justice of policies. In fact, as the administrative promotion hierarchy gets increasingly narrow, SOEs are good places for officials who cannot go further up the hierarchy. The high salaries and bonuses provided by SOEs can compensate for lack of upward mobility. According to figures in CNPC's annual reports, the per capita remuneration of the company's executives in 2007-2010 reached RMB 962,900; 892,300; 861,800 and 1.10 million. The more emphasis the administrative departments and people inside them put on their rent interest, the tighter the administrative monopoly will become.

Due to the political structure in China, enterprises seek the support of public power in a different way. In reference to the expression 'lobbying' in the USA, similar activity in China is called 'in-house lobbying'. That is to say, SOE management only needs to lobby the related administrative departments instead of the legislature. Because administrative departments are less transparent than the legislatureand there are special relations between SOE managers and government officials, it is called 'in-house lobbying'. Chinese enterprises can not only push administrative departments to enact regulations and policies (department legislation) conducive to their monopoly, they can also affect the laws promulgated by the legislature to form a pattern of administrative monopoly.

\section{Pathways for the Emergence of Administrative Monopoly in the Oil Industry}

\section{Establish Monopoly through 'Department Legislation'}

According to China's legislative practice, the National People's Congress and local people's congresses rely on administrative departments to draft bills. The official laws need to be specified by many administrative regulations (Unirule Institute of Economics 2012). In the absence of laws, industrial administration often relies on departmental bylaws. The absence of administrative departments opens a convenient door for enterprises to participate directly in drafting regulations.

In September 1988, the administrative department, the Ministry of Petroleum Industry, was dissolved and CNPC, Sinopec and CNOOC 
gained industry administration power in their respective areas. Under the current system, the government administration of the oil industry is distributed among different administrative departments. The exploration and exploitation of oil is under the Ministry of Land and Resources, the price is fixed by the National Development and Reform Commission, importing and exporting is decided by the Ministry of Commerceand the State Assets Administration Committee supervises the maintenance and development of state-owned assets. CNPC and Sinopec assume responsibility for oil production, operation and industrial adjustment, operating as an administrative department to some extent. Therefore, the three companies are always involved in drafting and making industrial regulations and policies. In this process, enterprises can secretly embody their interests and get monopoly through regulations, rules and policies. They can further extend their monopoly by implementing such regulations, rules and policies. By pushing the decision making of relevant ministries and commissionsand leveraging a series of regulations and policies, CNPC, Sinopec and CNOOC have a monopoly over the whole industry chain, from the upstream sector to retail.

\section{Set up Institutional Barriers to Entry}

The institutional barriers to entry of China's oil industry can be divided into explicit and implicit aspects. High entry thresholds are set for oil exploitation, refining, wholesaling and retailing of processed oil, importing and exporting crude oil and processed oiland oil reserves. Although the Measures for the Control of the Processed Oil Market, enacted in 2007, lifted the ban on wholesaling by private companies, the regulation raised the 'threshold' for wholesalers and retailers of processed oil The criteria for processed oil wholesalers include: over 1 million tons of crude oil processing capacity, no less than 0.5 million tons of annual gasoline and diesel oil production capacity, no less than RMB 30 million of registered capital, no less than $10,000 \mathrm{~m}^{3}$ of oil depot storage capacity, pipes, private railroads, road transport or more than 10,000 tons of shipping capacity for unloading and transferring processed oil. The entry thresholds for wholesale, storage, retail, import and export of crude oil and processed oil follow the policies of the former State Economic and Trade Commission. All these requirements are customized by SOEs that have already obtained monopolyand are almost unattainable for potential entrants.

In addition to explicit barriers, implicit institutional barriers also play an important role. For instance, to get import quotas, private companies 
need to meet the application criteria of the Ministry of Commerce. On top of that, they must obtain the certificates of production scheduling issued by CNPC and Sinopec. However, in reality, they can hardly get such certificates from the two giants.

\section{Enhance the Monopoly of the Three Oil Giants through Price Regulation}

In addition to conferring monopoly power to businesses by means of regulations and policies, administrative departments also further enhance the monopoly of the three oil giants through price regulation. Price regulation can be divided into two forms, regulation of seller's or selling priceand regulation of buyer's or buying price, which is reflected by the preference and even payment exemption to those in possession of administrative monopoly for resources and other inputs (Unirule Institute of Economics 2012).

\section{Regulation of seller's price}

Under China's administrative monopoly, price regulation is never used to mitigate the price distortion caused by market monopoly. On the contrary, because of price regulation, the product price and profitability of monopolists are increased, further distorting the prices and leading to exacerbated loss of social welfare. Although the pricing mechanism for processed oil in China seems to align with international practiceand the right to fix and adjust the price is reserved by the National Development and Reform Commission, the price is still very high. In 2012,

TABLE 2: Comparison of Average Pre-tax Gasoline Prices (US\$/gallon)

\begin{tabular}{|l|c|c|c|c|c|c|}
\hline & 2006 & 2007 & 2008 & 2009 & 2010 & 2011 \\
\hline Belgium & 2.26 & 2.50 & 3.20 & 2.21 & 2.72 & 3.49 \\
\hline France & 2.12 & 2.36 & 3.02 & 2.15 & 2.59 & 3.38 \\
\hline Germany & 2.15 & 2.38 & 2.91 & 2.15 & 2.58 & 3.31 \\
\hline Italy & 2.42 & 2.64 & 3.34 & 2.46 & 2.88 & 3.66 \\
\hline Netherlands & 2.49 & 2.87 & 3.51 & 2.31 & 2.68 & 3.44 \\
\hline UK & 2.14 & 2.35 & 2.95 & 1.93 & 2.46 & 3.21 \\
\hline USA & 2.40 & 2.62 & 3.15 & 2.19 & 2.63 & 3.36 \\
\hline International weighted average & 2.30 & 2.57 & 3.06 & 2.18 & 2.64 & 3.38 \\
\hline China & 2.07 & 2.26 & 2.80 & 2.72 & 3.22 & 3.92 \\
\hline
\end{tabular}

Source: US Energy Information Administration; price adjustment information on the websites of the National Development and Reform Commission and Beijing Municipal Development and Reform Commission. See the calculation at: http://www.unirule.org.cn/index. php?c=article\&id $=112$. 
China's average export price of processed oil was RMB 4.42/L. The tax-inclusive oil price calculated according to Sinopec's tax structure was about RMB 5.63/L. However, in 2012, the price of No. 92 gasoline was RMB 7.31-8.33/L in Beijing.

Since China's oil price began to align with international market prices in 2009, the pre-tax price of processed oil in China has been well above the international level (see Table 2). In 2009-2011, given the same quality standards, the pre-tax prices of gasoline and diesel oil in China were respectively 20 per cent and 29 per cent higher than the international prices (see Table 3 ). Therefore, it is obvious that China's current oil pricing mechanism expands the monopoly interest of oil companies. ${ }^{4}$

TABLE 3: Comparison of Average Pre-tax Diesel Oil Prices (US\$/gallon)

\begin{tabular}{|l|c|c|c|c|c|c|}
\hline & 2006 & 2007 & 2008 & 2009 & 2010 & 2011 \\
\hline Belgium & 2.39 & 2.64 & 3.82 & 2.30 & 2.84 & 3.75 \\
\hline France & 2.26 & 2.48 & 3.61 & 2.17 & 2.64 & 3.57 \\
\hline Germany & 2.27 & 2.56 & 3.63 & 2.26 & 2.70 & 3.64 \\
\hline Italy & 2.60 & 2.79 & 3.96 & 2.53 & 2.95 & 3.92 \\
\hline Netherlands & 2.47 & 2.77 & 3.94 & 2.27 & 2.67 & 3.70 \\
\hline UK & 2.31 & 2.50 & 3.58 & 2.15 & 2.58 & 3.48 \\
\hline USA & 2.22 & 2.43 & 3.39 & 2.00 & 2.54 & 3.36 \\
\hline International weighted average & 2.33 & 2.54 & 3.50 & 2.13 & 2.64 & 3.52 \\
\hline China & 2.15 & 2.44 & 3.03 & 2.95 & 3.51 & 4.25 \\
\hline
\end{tabular}

Source: US Energy Information Administration; price adjustment information on the websites of the National Development and Reform Commission and Beijing Municipal Development and Reform Commission. See the calculation at: http:/ / www.unirule.org.cn/index. php?c $=$ article\&id $=112$.

\section{Regulation of buyer's price}

The buyer's price refers to the price paid to owners of resource factors by monopoly enterprises as users. In China, the price of resource factors is not formed through the mechanism of market competition. Instead, it is a regulatory price fixed by the government. In contrast with the high seller's price, the factor price fixed by the government is lower than the market price.

Factors used by oil companies include land, oil resources, funds, etc. Before 2003, SOEs mainly acquired long-term land use rights through allocation at no cost or through transfer agreements at low prices. The land price was not actually reflected through the market mechanism. The land acquired by oil companies for no cost or at low prices includes land for industrial and commercial purposes. In terms of resource us- 
age cost, prior to 2011, the resource tax rate of oil was less than 2 per cent of the price, much lower than the international average rate of 10 to 20 per cent. The rights and interests of oil resource owners were not fully reflected and compensated. The fundraising costs of SOEs are also much lower than those of private companies. China's credit market is still dominated by the major state-owned commercial banks. There is government background in the economic behaviour of both SOEs and state-owned commercial banks. With government support, SOEs can get loans more easily and at preferential interest rates. For instance, the interest rate of credits granted by these banks to CNPC is 10 per cent lower than that of general loans to private enterprises. In addition, it is much easier for SOEs to get approval from administrative departments to raise funds by issuing bonds and other low-cost means. State-owned companies also receive a large amount in fiscal subsidies from the government.

As a result of low-cost acquisition and utilization of these factors, some rents are transformed into profits for monopolists and the operational effectiveness of these companies is exaggerated. Land resources, mineral resources and financial resources are actually monopolized by the government, which is constantly enhancing its control over these resources. It is because of such administrative monopoly that SOEs and private companies have severely unequal access to resources. The subsidy granted by the government to compensate the oil industry for paying for the production factors it uses further consolidates the competitive advantages of state-owned oil companies in the market and increases their profits. For the ultimate owners of resource factors, i.e. the people, the subsidy means a loss of welfare.

\section{Welfare Loss and Allocation Distortion Resulting from Monopoly in the Oil Industry}

\section{Composition of Welfare Loss and Allocation Distortion}

Under general administrative monopoly, the outputs of monopolists are lower than under perfect competition and their prices are higher than under perfect competition. Therefore, losses incurred to society include two parts: the net loss of social welfare caused by output reductionand transfer of consumer surplus to producers due to high monopoly prices. For society as a whole, the second transfer is a problem of resource allocation. However, such transfer causes monopoly rent, the alloca- 
tion of which includes three aspects: first, informal expenditures of administrative departments of the monopolized industries; second, high salaries and benefits of employees in monopolized industries; and third, non-productive expenditures of monopolists, such as duty consumption and other conspicuous consumption. In addition, rent seeking in monopolized industries will unavoidably cause corruption. According to Gordon Tullock (1967), the monopoly rent will ultimately be completely dissipated in a non-productive manner, thus becoming a welfare loss.

Administrative monopolists in China are quite peculiar in that their monopoly profits come from both high monopoly prices and lower prices for resource factors. For instance, administrative departments grant the resource use right to state-owned monopolists and symbolically collect a small resource occupation or use fee. As a result, a lot of resource rent is transformed into the profits of monopolists. The huge real costs in the book profits of these companies constitute the net transfer of social welfare to monopolists. However, such a transfer is not effectively transformed into more and better products. Therefore, from the perspective of society as a whole, this part is a loss, which should

FIGURE 2: Welfare Loss and Allocation Distortion Caused by Administrative Monopoly

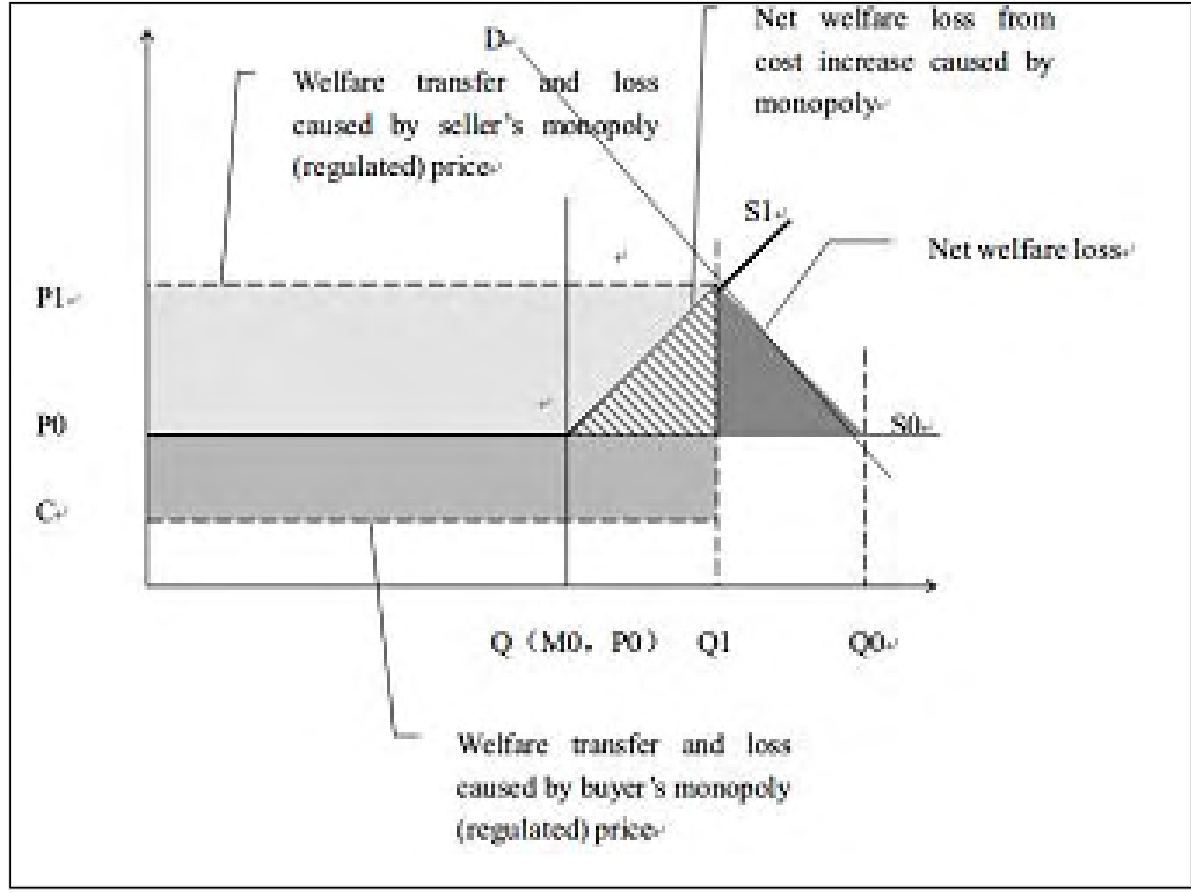

Source: Unirule Institute of Economics (2013a). 
be included in the efficiency loss of administrative monopoly (Unirule Institute of Economics 2013b).

Therefore, in China's oil industry, the welfare loss caused by administrative monopoly consists of three parts: as can be seen in Figure 2, the net welfare loss caused by price increase and production reduction resulting from administrative monopoly (triangle OS1S0), allocation distortion and welfare loss caused by price monopoly by buyers (quadrangle $\mathrm{P} 0 \mathrm{P} 1 \mathrm{~S} 1 \mathrm{O}$ )and the allocation distortion and welfare loss caused by price monopoly by sellers (rectangle CP0O1O2).

\section{Net Welfare Loss}

Cowling and Mueller (1978) assumed that a monopolist who seeks to maximize profit would choose to make the profit-sales ratio equal to the reciprocal of the price elasticity of demand: $(\mathrm{pm}-\mathrm{c}) / \mathrm{pm}=1 / \varepsilon$. In combination with Harberger's computing formula, Cowling and Mueller proposed the following formula to calculate the welfare loss of monopoly: $\mathrm{DWL}=\Pi / 2$, where $\Pi$ is the profit of the company, i.e. the welfare loss resulting from monopoly is half of the company's profit. The theory behind the study of Cowling and Mueller is optimal profit maximization behaviour. But obviously, the profit cannot be completely transformed into monopoly profit. Therefore, Cowling and Mueller's estimate is also called the upper limit estimate. According to the profits of oil and natural gas exploitation, oil processing and coking sectors in China Statistical Yearbook, the upper limit of net welfare loss resulting from monopoly in China's oil industry in 2001-2010 stood at around RMB 1.545 trillion.

TABLE 4: Profits of the Oil Industry (in RMB 100 million)

\begin{tabular}{|c|c|c|}
\hline Year & Profits of oil and gas exploitation & Profits of oil processing and coking \\
\hline 2001 & 978.15 & -12.05 \\
\hline 2002 & $1,170.45$ & 50.94 \\
\hline 2003 & $1,221.46$ & 123.41 \\
\hline 2004 & $1,744.65$ & 293.31 \\
\hline 2005 & $2,957.79$ & -119.27 \\
\hline 2006 & $3,652.12$ & -312.24 \\
\hline 2007 & $3,535.41$ & 216.15 \\
\hline 2008 & $4,601.23$ & $-1,003.14$ \\
\hline 2009 & $1,903.45$ & 931.24 \\
\hline 2010 & $3,026.76$ & $1,221.11$ \\
\hline 2011 & $4,299.6$ & 423.1 \\
\hline Total & $29,091.07$ & $1,812.56$ \\
\hline
\end{tabular}

Source: China Statistical Yearbook (2001-2010). 


\section{Allocation Distortion and Welfare Loss Resulting from Price Monopoly by Buyers}

The loss is the welfare transferred from resource owners to monopolists. The amount of transferred welfare equals at least the welfare that is lost. In a competitive market, these resources can be sold at market prices and more products will be produced. In the oil industry, the allocation distortion and welfare loss mainly involves fiscal subsidies granted by the government to monopolistic oil companies, fund-raising costs that are lower than the market level and the loss of land and resource rents.

\section{Lack of land rent}

In 2000, PetroChina signed a land use right rent agreement with CNPC. According to the agreement, CNPC would rent about 1.145 billion $\mathrm{m}^{2}$ of land to PetroChina for 50 years at a rent of only RMB 2 billion a year. The unit rent is only $\mathrm{RMB} 1.75 / \mathrm{m}^{2}$ per year, much lower than the rent of land for industrial purposes in the market. Moreover, CNPC did not turn the rent over to the government.

According to the Ministry of Land and Resources' fixed base index ${ }^{5}$ for land for industrial purposes, the annual rent of land for industrial purposes is calculated at a rate of 3 per cent of the land price. Accordingly, the underpayment of land rent by PetroChina totalled RMB 188.6 billion in 2001-2011 (Table 5). This figure is still underestimated because part of the land rented by PetroChina is used for commercial purposes rather than industrial purposes.

TABLE 5: Estimate of Rent Underpayment by PetroChina for Land Used for Industrial Purposes (2001-2011)

\begin{tabular}{|l|l|l|l|l|l|l|l|l|l|l|l|}
\hline & 2001 & 2002 & 2003 & 2004 & 2005 & 2006 & 2007 & 2008 & 2009 & 2010 & 2011 \\
\hline $\begin{array}{l}\text { Priceoflandfor } \\
\text { industrial pur- } \\
\text { poses (RMB/ } \\
\mathrm{m}^{2} \text { ·year) }\end{array}$ & 453 & 466 & 493 & 502 & 511 & 524 & 608 & 604 & 617 & 662 & 697 \\
\hline $\begin{array}{l}\text { Rent under- } \\
\text { payment } \\
\text { (RMB 100 } \\
\text { million) }\end{array}$ & 136 & 140 & 149 & 152 & 155 & 160 & 189 & 187 & 192 & 207 & 219 \\
\hline
\end{tabular}

Source: Price of land for industrial purposes is taken from the website of the Ministry of Land and Resources, available at: http://www.landvalue.com.cn/Default.aspx.

If the land price fixed by means of bid tendering, auction and quotation is the market price, the adoption of bid tendering, auction and quotation to fix the price of land for gas stations started in China in 2003. 
During 1990-2002, land allocation and assignment by means of agreement co-existed. Because the price of land assigned by agreement was much lower than the market price, the land rent was underestimated. According to the Ministry of Land and Resources' fixed base index ${ }^{6}$ of the land for commercial and service purposes, the annual rent of land for commercial and service purposes is calculated at a rate of 5 per cent of the land price. According to the average price of land for commercial and service purposes between 2003 and 2010, it is estimated that the underpayment of rent for land of gas stations by CNPC and Sinopec totalled RMB 207.1 billion (Unirule Institute of Economics 2012).

TABLE 6: Estimate of Rent Underpayment by CNPC and Sinopec for Land Used for Gas Stations (2003-2011)

\begin{tabular}{|l|c|c|c|c|c|c|c|c|c|}
\hline & 2003 & 2004 & 2005 & 2006 & 2007 & 2008 & 2009 & 2010 & 2011 \\
\hline $\begin{array}{l}\text { Price of land for } \\
\text { commercial and } \\
\text { service purposes } \\
\text { (RMB/m } \text { m }^{2} \text { year) }\end{array}$ & 4,263 & 4,547 & 4,760 & 4,973 & 5,471 & 5,542 & 5,862 & 6,537 & 7,176 \\
\hline $\begin{array}{l}\text { Rent underpay- } \\
\text { ment (RMB 100 } \\
\text { million) }\end{array}$ & 178 & 190 & 199 & 209 & 231 & 234 & 248 & 277 & 305 \\
\hline
\end{tabular}

Source: The prices of land for commercial and service purposes are calculated according to data on the website of the Ministry of Land and Resources, available at: http:/ /www.landvalue. com.cn/Default.aspx.

\section{Lack of resource rent}

Oil and gas resource taxes, mineral resource compensation, mining royalties and special oil gains constitute the system of resource taxes in China's oil and natural gas industry. The resource taxes and fees represent the rents collected by resource owners, which can be divided into absolute rent and differential rent. Resource rent, mineral resource compensation and mining royalties fall into absolute rent, which should be incorporated into product cost. As a differential rent, special oil gains refers to the rent collected for the part in excess when the price of crude oil exceeds a certain amount.

TABLE 7: Underpayment of Oil Rent by CNPC and Sinopec, 2001-2011 (in RMB 100 million)

\begin{tabular}{|l|l|l|l|l|l|l|l|l|l|l|l|}
\hline & 2001 & 2002 & 2003 & 2004 & 2005 & 2006 & 2007 & 2008 & 2009 & 2010 & 2011 \\
\hline $\begin{array}{l}\text { Underpay- } \\
\text { ment of oil } \\
\text { rent }\end{array}$ & 194 & 190 & 238 & 285 & 473 & 308 & 309 & 290 & 311 & 301 & 181 \\
\hline
\end{tabular}

Source: Calculated according to data in the annual reports of CNPC and Sinopec. 
In general, the resource rate in China is still quite low. According to figures in the annual reports of CNPC and Sinopec, the resource rate of the oil industry has long been below 1 per cent, much lower than the rate in many other countries. The interests of oil resource owners are not fully reflected and safeguarded. Although as of November 2011, the resource rate of oil and natural gas was raised to 5 per cent, it is still lower than the rate in many other countries, where the rate is 10 to 20 per cent.

In this article, when calculating the payable resource rent, if the oil price is lower than US\$ 40, the rent should be 10 per cent of the price. The part in excess of US\$ 40 should be calculated according to the criteria of special oil gains in China. With the resource rent that was paid being deducted, the underpayment of rent by oil companies in 2001-2011 totalled RMB 308 billion (Unirule Institute of Economics 2012).

\section{Underpayment of interest}

Monopolistic oil companies in China have been gaining a large quantity of financial resources at a cost much lower than market interest rates, leading to the improper allocation of financial resources, that is, savings that fundamentally belong to people are used to subsidize monopolistic oil companies. In 2000-2007, the weighted average interest rate of loans for the manufacturing sector (exclusive of SOEs) was 4.68 per cent (Unirule Institute of Economics 2013c). According to figures disclosed by CNPC, Sinopec and CNOOC, the weighted average interest rate of their loans was 1.02 per cent, 1.58 per cent and 1.13 per cent respectively. If calculated at the 4.68 per cent market interest rate, the underpayment of interest by the three monopolistic oil companies totalled RMB 287.9 billion in the past ten years.

TABLE 8: Underpayment of Fund Costs by CNPC, Sinopec and CNOOC, 2001-2011 (in RMB 100 million)

\begin{tabular}{|l|c|c|c|c|c|c|c|c|c|c|c|}
\hline Year & 2001 & 2002 & 2003 & 2004 & 2005 & 2006 & 2007 & 2008 & 2009 & 2010 & 2011 \\
\hline $\begin{array}{l}\text { Underpay- } \\
\text { ment of } \\
\text { fund costs }\end{array}$ & 96 & 96 & 130 & 160 & 197 & 200 & 241 & 268 & 383 & 474 & 634 \\
\hline
\end{tabular}

Source: Calculated according to data in annual reports of CNPC, Sinopec and CNOOC.

\section{Government subsidy}

In 2001-2010, CNPC and Sinopec received a total of RMB 100.8 billion in subsidies from the government. In 2009, although the oil price in China was much higher than the crude oil price on the international market, 
CNPC still received a subsidy of RMB 1.097 billion from the government as 'the fiscal support subsidy that should be paid to CNPC for ensuring the supply of crude oil and processed oil in China' according to the 2008 annual report of CNPC. In contrast, privately owned local refineries failed to receive any refining subsidy or establish downstream sales systems in more than ten years.

The loss in oil refining has been an excuse used by oil refineries to apply for government subsidies. Despite the loss, this sector has not been fully opened to other capital, mainly because state-owned oil refineries can encroach on the profits of private capital through monopoly and can further squeeze the profitability of private refineries and gas stations. This has been proven by the large losses of CNPC and Sinopec in oil refining and their huge overall profits.

\section{Methodology}

Through monopolistic prices, consumer surplus is transferred to producers. Although superficially it is a transfer of welfare, monopoly profit can eventually be translated into high benefits to monopolist employees, duty consumption and other types of corruption of managers. Therefore, in terms of opportunity cost, it is a loss of welfare, because the welfare transferred to monopolists is not used for productive activities. If used for productive activities, the welfare would produce at least the same amount of value.

Due to the difference in the average processed oil price in China and the weighted average price on the international market, the transfer and loss of welfare totalled RMB 437.8 billion during 2006-2010 .

TABLE 9: Welfare Loss Resulting from Price Monopoly (in RMB 100 million)

\begin{tabular}{|l|l|l|l|l|l|}
\hline & 2006 & 2007 & 2008 & 2009 & 2010 \\
\hline Gasoline & -385 & -503 & -454 & 971 & 1,177 \\
\hline Diesel oil & -537 & -311 & $-1,395$ & 2,635 & 3,179 \\
\hline Total & -922 & -813 & $-1,850$ & 3,607 & 4,356 \\
\hline
\end{tabular}

Note: Sinopec's sales of gasoline and diesel oil are calculated at a ratio of 1:2.

Source: Sales data of gasoline and diesel oil are taken from the annual reports of CNPC and Sinopec (2006-2011).

\section{Total Welfare Loss}

According to the above calculations and analysis, the total welfare loss resulting from administrative monopoly in China's oil industry includes (1) net welfare loss caused by monopoly; (2) underestimated costs, in- 
cluding government subsidies, fund-raising costs, land rent and resource rent; and (3) monopoly profits brought by high monopoly prices. The welfare loss totals RMB 2.7 trillion, accounting for 105 per cent of the profit of China's oil industry (Table 10).

TABLE 10: Total Welfare Loss of Monopolistic Oil Companies, 2001-2010 (in RMB 100 million)

\begin{tabular}{|l|c|c|c|c|c|c|c|c|c|c|}
\hline Year & 2001 & 2002 & 2003 & 2004 & 2005 & 2006 & 2007 & 2008 & 2009 & 2010 \\
\hline $\begin{array}{l}\text { Net wel- } \\
\text { fare loss }\end{array}$ & 483 & 611 & 672 & 1,019 & 1,419 & 1,670 & 1,876 & 1,799 & 1,417 & 2,124 \\
\hline $\begin{array}{l}\text { Govern- } \\
\text { ment } \\
\text { subsidy }\end{array}$ & -- & -- & -- & -- & 98 & 58 & 61 & 672 & 11 & 27 \\
\hline $\begin{array}{l}\text { Fund-rais- } \\
\text { ing cost }\end{array}$ & 96 & 96 & 130 & 160 & 197 & 200 & 241 & 268 & 383 & 474 \\
\hline Land rent & 136 & 140 & 327 & 343 & 355 & 369 & 419 & 421 & 440 & 484 \\
\hline $\begin{array}{l}\text { Resource } \\
\text { rent }\end{array}$ & 194 & 190 & 238 & 285 & 473 & 308 & 309 & 290 & 311 & 301 \\
\hline $\begin{array}{l}\text { Seller's } \\
\text { monopoly }\end{array}$ & -- & -- & -- & -- & -- & -922 & -813 & $-1,850$ & 3,607 & 4,356 \\
\hline Total & 909 & 1,037 & 1,367 & 1,807 & 2,542 & 1,683 & 2,093 & 1,600 & 6,169 & 7,766 \\
\hline
\end{tabular}

Source: Calculated according to data in annual reports of CNPC, Sinopec and CNOOC.

\section{Wealth Redistribution Mechanism}

The use of resources at very low prices or for free transforms part of the rent of resources into the profit of the oil enterprises. In addition, subsidies from the government and the monopoly profits from the administrative monopoly status benefit these oil enterprises and make them appear profitable. The turnover of revenues and the income distribution system make high-ranking executives and ordinary staff the biggest beneficiaries.

Before the release of Suggestions on Operating Budget for State-Owned Capital (State Council [2007] No. 26) by the State Council, it had been 13 years since SOEs had turned over any of their profits. It was not until 2008 that the central government implemented the Suggestions and made central government-led state-owned enterprises budget their operating capital. Nevertheless, the turnover revenue of SOEs even today accounts on average for less than 10 per cent of their profits.

The huge nominal profits have attracted significant interest from the most important executives in senior management of central governmentled SOEs. Even with the 10 per cent turnover of revenues, this group still holds most of the profits of most of the SOEs. The true owners of 
FIGURE 3: Flow of Revenues

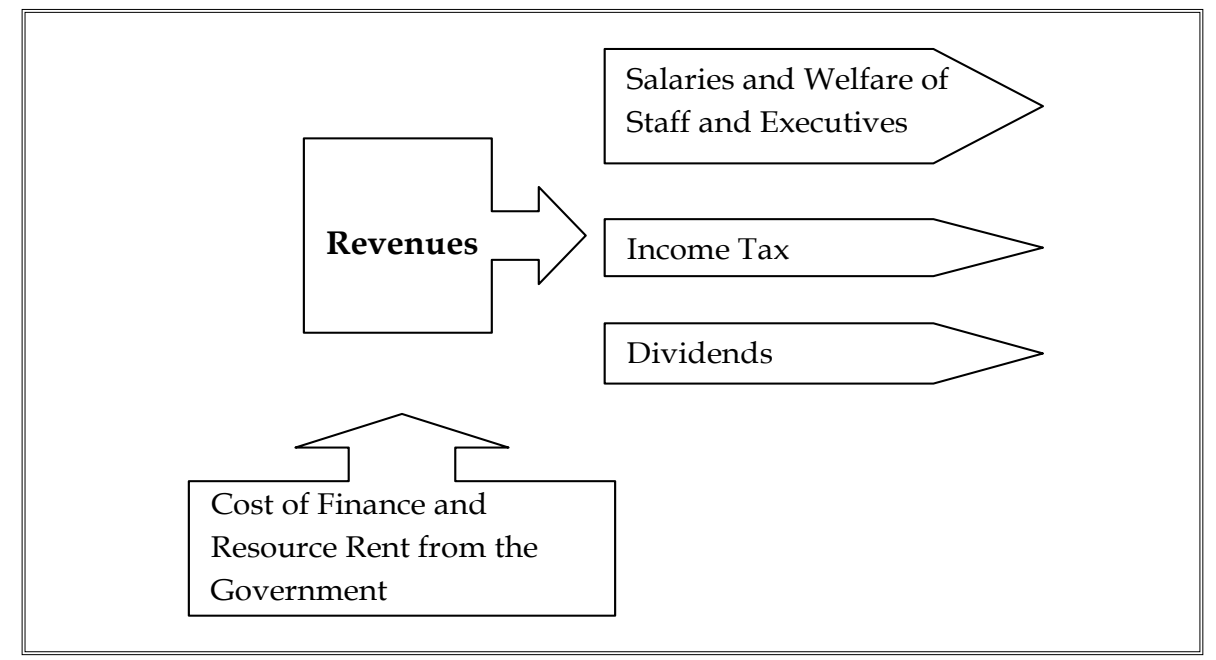

the resources (Chinese nationals) and their surrogate (the government) have not acted on their rights as owners and managed the nominal revenues directly. Because the $\mathrm{C}$-suites of the SOEs decide salaries and bonuses for themselves and their staff, the revenues of the SOEs flow mostly into these two areas after business income taxes.

In 2011, the State Economic and Trade Commission released Suggestions on Deepening Reform of the State-Owned Enterprise Internal Personnel, Labourand the Distribution System. Here, SOE senior management was entrusted with 'self-determining' salary standards for their staff. Even with the overall salary budget controlled by the State-owned Assets Supervision and Administration Commission (SASAC) in 2010, the room to manoeuvre was still large. In 2010, the average salary for CNOOC was ten times that of the social average of Chinese people according to data from China Statistical Yearbook that year. In 2011, the average income of the oil industry was about 4.5 times that of the social average. In addition to the nominal income gap on the books, there are invisible bonuses and subsidies for staff of central-government-led SOEs, including housing subsidies and medical subsidies.

In December 2009, SASAC released Interim Procedures to Assess the Performance of Central Government-Led State-Owned Enterprise Executives, requiring that executive salaries be pegged to the enterprise's performance. However, there is a serious overlap in the internal governance structure of the SOEs as the members of the board can also shoulder managerial duties, which facilitates the so-called 'internal control'. This disables the independence of the salary system for executives in SOEs. 
FIGURE 4: Income of the Staff of the Three Big Oil Enterprises and the Social Average (in RMB)

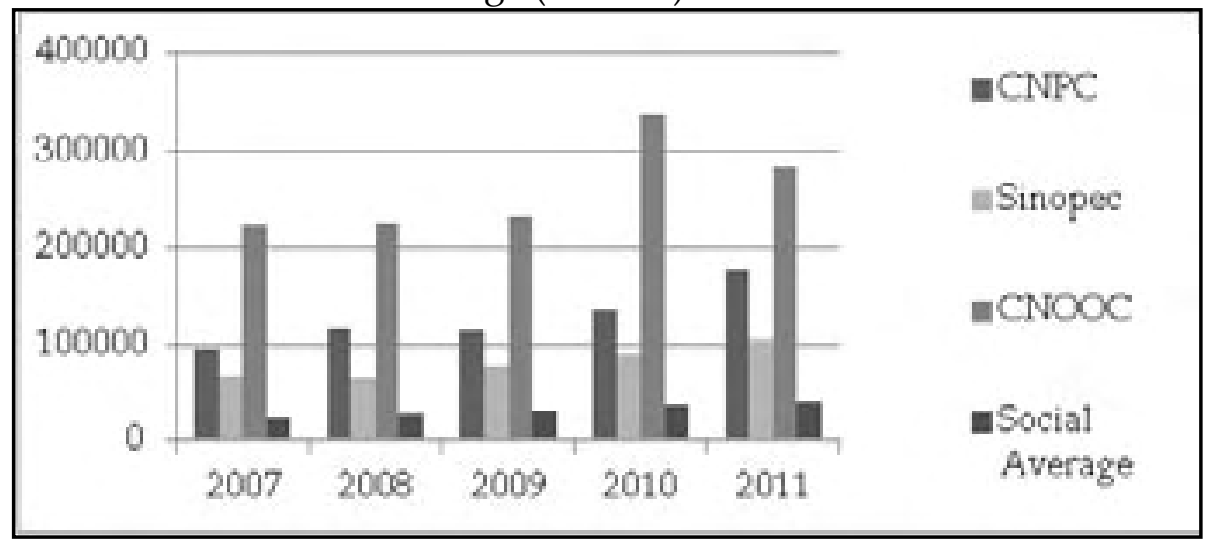

Source: Annual reports of the enterprises and China Statistical Yearbooks.

In recent years, the annual salary of high-ranking executives of CNPC accelerated to RMB 1 million; meanwhile, the nominal net profit margin decreased. The connection between the income of executives and the performance of the enterprises is missing. Besides, this performance is not based on fair competition according to the market rules.

TABLE 11: Income of Executives of the Oil Industry (in RMB 10,000)

\begin{tabular}{|c|c|c|c|}
\hline & CNPC & Sinopec & CNOOC \\
\hline 2007 & 96 & 80 & 844 \\
\hline 2008 & 89 & 82 & 949 \\
\hline 2009 & 86 & 72 & 1,097 \\
\hline 2010 & 110 & 97 & 1,014 \\
\hline 2011 & 101 & 97 & 603 \\
\hline
\end{tabular}

Note: Based on the average of the three highest incomes for executives. For CNOOC, option incomes of the executives are included.

Source: Annual reports of enterprises.

In addition to nominal incomes, on-the-job consumption and invisible salaries and bonuses are paid to the executives and staff of the oil enterprises, which are not disclosed in the annual reports. According to the research of the Report on Executive Compensation Index of China's Listed Companies (2011), taking CNPC as an example, the on-the-job consumption and invisible bonuses and subsidies can be calculated roughly by assessing the non-operating money flow disclosed by their annual reports. We concluded that the invisible compensations are considerably higher than the nominal income of the high-ranking executives. 
FIGURE 5: Nominal Net Profit Margin of CNPC

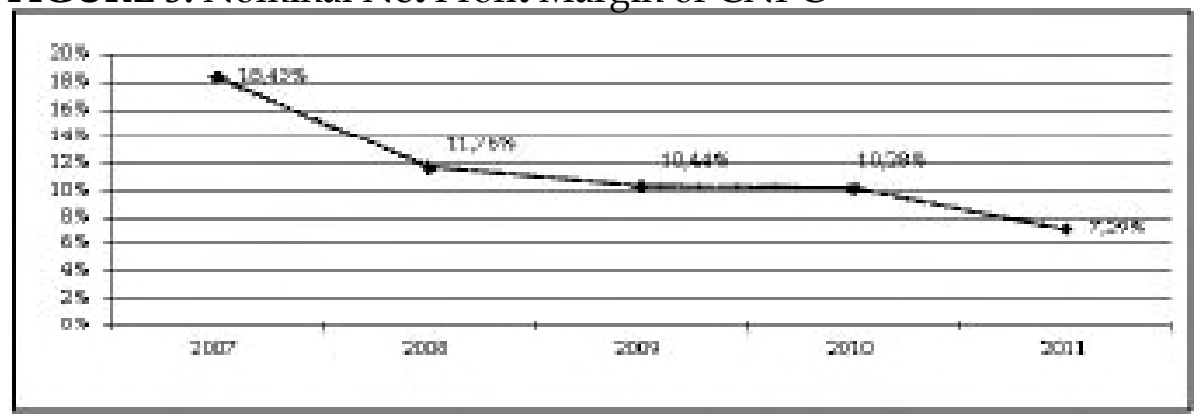

Source: Calculated according to the data in the annual reports of CNPC (2006-2011) and China Statistical Yearbook.

TABLE 12: On-the-Job Consumption and Invisible Compensation for Staff and Executives of CNPC

\begin{tabular}{|c|c|c|}
\hline Year & $\begin{array}{c}\text { On-the-Job Consumption } \\
\text { (RMB 100 million) }\end{array}$ & $\begin{array}{c}\text { Average Invisible Compensa- } \\
\text { tion (RMB 10,000) }\end{array}$ \\
\hline 2007 & 567.97 & 14.56 \\
\hline 2008 & 535.14 & 14.46 \\
\hline 2009 & 647.56 & 14.51 \\
\hline 2010 & 749.5 & 16.55 \\
\hline
\end{tabular}

Source: Gao (2011).

Most of the monopoly revenues of the oil enterprises become consumption for non-production purposes, which from the perspective of opportunity cost, is a welfare loss. In addition, the administrative monopoly results in huge resource allocation losses and low efficiencyand is a major cause of the unfair income distribution in China.

\section{Measures to Break Administrative Monopoly in the Oil Industry}

The administrative monopoly in China's oil industry stems from a series of regulations enacted by administrative departments. These 'department legislations' jeopardize the sound development of the oil industry, affect the effective supply of oil products and undermine fair competition in the industry. Whether the existing administrative monopoly in the oil industry can be broken and administrative monopoly of interest groups over the industry can be eradicated depends mainly on the faith and resolve of politicians. On this basis, we should do the following. 
First, identify the reform objectives and reach consensus on boosting the reform of the crude oil and processed oil markets. Specifically, an oil and natural gas industry system based on the market system needs to be established. Because oil and natural gas have the nature of private goodsand their production has a competitive nature, the oil and natural gas industry should adopt the market system as its fundamental system. This means that enterprises can enter the industry freely, enterprises in this industry have equal rights, no enterprises should have access privileges or preferential prices for resources and the government should not intervene in the price, output or number of enterprises in this industry.

Under a market system, the basic function of the government is to protect property rights, safeguard market order and create and maintain an environment for competition. The government should stop and punish any violation of market rules. For instance, in the case of unfair competition, the government should stop it and punish it in accordance with the law.

In addition, a fair and effective pattern for market competition across the oil and natural gas industry must be created. In the oil industry chain, due to the high risks led by inadequate exploration and the intrinsic monopoly nature in oil transportation, the government should provide appropriate subsidies and regulations to promote market competition. However, the refining, wholesale, retail and trade sectors should be open to enterprises for free competition and the government should safeguard the fair play mechanism.

Second, to achieve these reform objectives, the following measures should be taken: (1) cancel the administrative monopoly of the oil giants and take back the administrative power conferred on them; (2) establish an independent and neutral regulatory institution for supervision of safety, technology, environmental protection and quality in the energy industry; (3) liberalize all sectors of the oil and petrochemical industry for the free entry of enterprises; and (4), eradicate price regulation.

The reform actually consists of two important aspects: deregulate the market and liberalize the price. Deregulating the market would mean lifting the ban in the crude oil and processed oil markets so that every enterprise can enter the market freely. If the entry of all enterprises needs to be regulated, the regulatory institution must specify the reason and get approval from the legislature to exercise regulation. Entry regulations should apply to all enterprises equally. Liberalizing the price would mean eliminating the price regulation of crude oil 
and processed oil after the crude oil and processed oil markets are deregulated to form market prices resulting from competition among many enterprises.

\section{Comments on Proposals to Reform the Oil Industry}

The report of the Unirule Institute of Economics ${ }^{7}$ on deregulating the crude oil and processed oil markets points out that market deregulation is a reform in tradeand it presents the following characteristics and benefits.

First, compared with other reforms in the oil and natural gas industry, the deregulation of oil and the processed oil market is quite flexible and less costly.

Reforms in other areas of the oil and natural gas industry, such as exploration, mining and refining, involve relevant laws such as the Minerals Law, or involve the core part of the existing administrative monopoly. The deregulation of the crude oil and processed oil markets only involves market entry. Although there are some administrative documents (such as Document No. 38) that hamper the entry of enterprises, they are at lower legal levels and it is easier to make breakthroughs.

Second, the deregulation of crude and processed oil markets will facilitate reform in mining, refining and other production areas. When the crude oil and processed oil markets are deregulated, market prices will be formed through competition. This price will squeeze the bubble in the regulated monopoly price, reduce the nominal profit of monopolists and facilitate reform to break up monopolies. On the other hand, because of increased crude oil supply, private and other refineries will grow.

Third, when the crude oil and processed oil markets are initially deregulated, the interest of existing monopolists is not directly harmed. Because there is not much difference in prices of crude oil and processed oil in China and the international market, the entry of new enterprises will not cause dramatic changes in the price within a short time. Therefore, the interest of existing enterprises in the market will not be reduced much. As a result, they will pose less resistance to deregulationand the reform will proceed without much difficulty.

Fourth, the deregulation of the crude oil and processed oil markets will prime the pump for reform in other areas of the oil and natural gas industry. The deregulation of the crude oil and processed oil markets will eventually result in the unification of domestic crude oil and processed markets. Therefore, to change the price in China's crude oil and processed oil markets and send the right price signal will boost 
the growth of non-monopolistic oil companies, change the supply and demand of crude oil and processed oil in Chinaand even reshape the world's energy pattern.

Fifth, the deregulation of the crude oil and processed oil markets will enhance the cooperation and economic and trade integration between China and its economic partners.

\section{Conclusion}

We can see that SOEs (especially CNPC, Sinopec and CNOOC) can attain industry monopoly with concessions granted by the government. The institutional framework enables them to get resource factors at low costs and control the upstream industry chain. They can further extend their monopoly to the whole industry, protect their vested interestsand refuse to deal with real stakeholders, i.e. they will ensure maximum department interest through discriminatory selection in market deals. Undoubtedly, this behaviour will have severe consequences. It has been proved that selective deals under industry monopoly will compromise social justice, affect efficiency, restrict the growth of the private sector and market economy, reduce total social welfare and increase the transaction cost for the whole society. Moreover, because the fundamental principle of the market economy is damaged, private companies have to collude with or even bribe resource controllers to get resources, which will lead to the degradation of business ethics. Therefore, China's reform must be further deepened. This will inevitably touch the vested interests of monopoly groups in the industryand that is where the reform difficulty lies. To break the administrative monopoly requires judicial, administrative and market means. It takes courageand more importantly, wisdom and viable approaches to advance this reform.

Gao Yan, Professor, Vice President of China Chamber of Commerce for Petroleum Industry; Deputy Director of Unirule Institute of Economics; Beijing Polytechnic. Email: gaoyan@unirule.org.cn

Qian Pu, Deputy Director, China Centre for Public-Private Partnerships, Unirule Institute of Economics. Email: qianpu@unirule.org.cn 


\section{NOTES}

1 All-China Federation of Industry and Commerce, 2006, 'Proposals about seriously implementing the Document No. 38 of the State Council to create a fair playing field for private petroleum enterprises'.

2 Yang Zhongxu 2012, 'Glass Door in the Oil Industry: Private Oil Companies Constrained in the Upstream and Downstream Business'. Caijing Magazine.

3 In Sam Peltzman's 'The Economic Theory of Regulation after a Decade of Deregulation', he pointed out that 'self-interested politicians and constituents exchange objects of utility - a price or entry certificate for votes and money - and what matters to each actor is their wealth or utility, not the aggregate social wealth'.

4 Chen Yongjie, 2012, 'The RMB 100 billion refining loss claimed by CNPC and Sinopec is much exaggerated', overseas edition of People's Daily, 2 April, p. 2.

5 The fixed base index of land for industrial purposes uses the average price of land for industrial purposes in major Chinese cities in 2000 as the baseand the index number is a ratio of the annual average price of land for industrial purposes and the average price in 2000.

6 The fixed base index of land for commercial purposes uses the average price of land for commercial purposes in major Chinese cities in 2000 as the baseand the index number is a ratio of the annual average price of land for commercial purposes and the average price in 2000 .

7 Unirule Institute of Economics (2013a). The original report was published in Chinese. An English version will be published by World Scientific Press in 2014.

\section{REFERENCES}

Cowling, Keithand Dennis C. Mueller 1978. 'The Social Cost of Monopoly Power'. The Economic Journal 88 (1): 724-748.

Gao Minghua 2011. Report on Executive Compensation Index of China's Listed Companies. Beijing: Economic Science Press.

Peltzman, Sam 1989. 'The Economic Theory of Regulation after a Decade of Deregulation'. Brookings Papers on Economic Activity, Microeconomics.

Tullock, G. 1967. 'The Welfare Costs of Tariffs, Monopoly and Theft'. Western Economic Journal 5 (3): 224-232.

Unirule Institute of Economics 2012. Cause, Behaviour and Eradication of Administrative Monopoly in China. Available at: http://www.unirule.org.cn/index. php?c $=$ article\&id $=211$.

Unirule Institute of Economics 2013a. 'Theoretical Research on and a Reforming Solution to Opening the Markets of Crude Oil and Petroleum Products'.

Unirule Institute of Economics 2013b. Deregulation Plan for China's Crude Oil and Processed Oil Market. Available at:

http:/ / www.unirule.org.cn/index.php?c=article\&id=112.

Unirule Institute of Economics 2013c. The Nature, Performance and Reform of the StateOwned Enterprises. Singapore: World Scientific Press.

Yu Huayang 2008. 'Theoretical Hypothesis that Administrative Monopoly Stems from Operating Mechanism - Based on the Perspectives of Institutional Demand and Supply'. Research on Financial and Economic Issues (1): 29-35.

Yu Hui 2000. 'Alliance between the Government and Enterprises in a Regulated Market with China's Telecom Industry as Example'. China Industrial Economics 1: 63-67. 